\title{
Students, Radicalism, and Entrepreneurship (A Case Study at IAIN Curup)
}

\author{
Hendra Harmi, Lukman Asha, Yuyun Yumiarty \\ Institut Agama Islam Negeri (IAIN) Curup, Indonesia \\ hendraharmi@iaincurup.ac.id, lukmanAsha@iaincurup.ac.id, \\ yuyunyumiarty@iaincurup.ac.id
}

\begin{abstract}
The objectives of this study were to find out the extent of radicalism-related understanding and symptoms amid the students of IAIN Curup and to know the policies made by the campus in countering radicalism. This study applied a descriptive analytic method adopting a phenomenological approach that deployed some techniques of collecting data such as observations, interviews, and documentation. This study revealed that the understanding of radicalism among the students of IAIN Curup was associated with religious radicalism. However, there was no any radicalism symptom found. In general, the students of IAIN Curup still had the spirits of Pancasila, Bhineka Tungga Ika, NKRI and the 1945 Constitution. The policies made by the campus in counteracting radicalism extended to strengthening the understanding of diversity, the mastery of scientific fields, and entrepreneurship. Students had an understanding of religious tolerance and accepted the presences of others. An active engagement into students' activities made them stay focused on the objectives of lecturing and learning. Through entrepreneurship activities, students became creative and innovative so that they were not easily drawn into radical actions.
\end{abstract}

Keywords: Students, Radicalism, Understanding of Diversity, Mastery of Scientific Fields, Entrepreneurship

\section{Introduction}

Indonesia is a country with Muslims as the majority of population. However, since the independence of Indonesia was proclaimed, it has been stipulated as a country that is not based upon Islamic law, but it is also not a secular state separating religion from the citizens' social lives. This heterogeneity is viewed by experts as a source of conflict that could threaten the nation's unity because each religious adherent has a sacred mission to spread his religion to people who are not of his religion. 
Education has a strategic role as a means of investing in human resources. Besides aiming for developing a better life, education has obviously espoused to color and become the moral and ethical foundations in the process of empowering the nation's identity (Hasan, $2000)^{1}$, including Islamic education in this regard.

Nonetheless, nowadays, Islamic education in Indonesia is more oriented towards building ritual piety. In the meantime, Islamic teachings associated with social piety such as anti-wealth accumulation, poverty alleviation, and coping with inequality are rarely discussed. This could potentially lead to radical attitudes.

In June 2017, the Minister of Research, Technology, and Higher Education, Muhammad Nasir said that the potential for radicalism is also growing among students ${ }^{2}$. This statement was also supported by the National Counterterrorism Agency (in Indonesian abbreviation, BNPT) in a dialogue with the theme of da'wah institutions' and campus bureaucracies' involvement in preventing terrorism in September 2017. As a matter of fact, Bengkulu is alleged to be one of the five provinces that has the potential for high radicalism. ${ }^{3}$

From the results of investigations carried out in July 2018, there was a phenomenon that occurred at the State Islamic Institute of Curup (hereafter as IAIN Curup). There were several students who took part in organizations and groups of Islamic sermons outside the campus. Those students brought their group habits to campus, thus bringing about changes in attitude and behavior towards the outsiders of their group. The dynamics of student's perspectives, mindsets and appearances have to some extent changed. At IAIN Curup, the more observable change was the way some female students wore the hijab. Since the last three years, hijab syar'i as a trend has been widely worn by the majority of female students, which at first was only worn by a few people. Hijab syar'i is considered capable of confirming to the existing regulations applied on campus because at the same time it will affect students' way of dressing.

\footnotetext{
${ }^{1}$ Hasan, K. (2000). Konsep Pendidikan Jawa. Jurnal Dinamika Islam dan Budaya Jawa, IAIN Walisongo Semarang . Vol. 3 No. 1. P. 29

2 DetikNew.com, accessed on the 5th of October 2017

${ }^{3}$ Viva.co.id, accessed on the 20th of December 2017
} 
As the foregoing, one of the regulations applied by the campus is to demand any female student to wear a hijab that covers the chest. Along with that, the campus gradually begins to be colored by the presence of some female students wearing complete veils that cover their faces. Initially, they just added to wear masks, but they subsequently proceeded to wear niqob (a special mask commonly worn by a female Muslim to cover her face as a part of her complete veil). In fact, the number of female students who wear niqob is increasing from year to year. It is undeniable that this at some point leads to friction among the academic community of IAIN Curup between those who are pro and contra to such a change. In respect of the foregoing phenomenon, the campus needs to take steps to find out the extent to which radicalism develops among the students of IAIN Curup.

Departing from the aforesaid issues, this study formulates problems related to the extent of students' understanding of radicalism and the symptoms of radicalism among students at IAIN Curup, as well as related to what policies are made by the campus in countering the radicalism.

\section{Radicalism}

Radicalism is an attitude or action towards various changes in the established order of life. Massively changing the world order has become the goal of radicalism today, in addition to the desire to change the existing order in a particular region or country (Sedjana, 2008). ${ }^{4}$

The term radicalism does not have a single definition. Also, not all circles of the community accept it. Each group has a different definition of radicalism, thus giving rise to a variety of meanings in each use of the definition. The terms that are often used interchangeably because they are considered having the same meaning as radicalism are such as terrorism, intolerance and militancy. According to Alex P. Schmid, radicalism is understood as the tendency of individuals or groups of people to confront and choose conflicts with parties of different views. This is supported by choosing the path of violence or non-violence,

\footnotetext{
${ }^{4}$ Sedjana, E. (2008). Islam Fungsional. Jakarta: Rajawali. P. 100
} 
espoused by strategies of pressure and coercion, considering terrorism as a noble act accompanied by various acts of violence, which in the end they will commit acts of extreme violence as a manifestation of the highest level of attitude against dialogues and compromises. The tendency to form a strong ideology is based on the view and belief that the existing system is not able to provide a way out for the expected changes, so that the path of violence is chosen as an alternative to realize their desires. This view is expressed in an article entitled "Radicalization, DeRadicalization, Counter-Radicalization: A Conceptual Discussion and Literature Review" (Ahnaf, 2013). ${ }^{5}$

Radicalism views a system that exists in society as having to undergo change and replacement to its roots. This can be done by any means of violence if deemed necessary. Changes in certain conditions and in all lines of public life in total are what radicals want, and they take account of their acts as well-planned and ideal things.

Viewed from a religious perspective, fanaticism towards a particular religion is another form of radicalism. Fanatically religious people tend to think that they are the most righteous compared to the adherents of different religions or sects, so it is not uncommon for the path of violence to be chosen as an act of coercion so that what they believe can be accepted by other parties (Yunus, 2017). ${ }^{6}$ Basically, there are no religious doctrines that teach about violence. However, it cannot be denied that there is an expression of terrorism as a consequence of the lack of proper interpretation and understanding of religion. (Qodir, 2013) $)^{7}$

Terminologically, terrorism is the use of terror as a symbolic act designed to influence policies and political behavior in extra normal ways,

${ }^{5}$ Ahnaf, M. I. (2013). Struktur Politik dan Deradikalisasi Pendidikan Agama Bagi Anak Muda Indonesia. Jurnal Pendidikan Islam FTIK UIN Sunan Kalijaga Yogyakarta. Vol. 2 No. 1, P. 159

${ }^{6}$ Yunus, A. F. (2017). Radikalisme, Liberalisme, dan Terorisme : Pengaruhnya Terhadap Agama Islam. Jurnal Studi Al-Qur'an .Vol. 13 No. 1. P. 5

${ }^{7}$ Qodir, Z. (2013). Deradikalisasi Islam Dalam Prespektif Pendidikan Agama. Jurnal Pendidikan Islam . Vol. 2 No. 1. P. 90 
especially using threats and violence that can lead to murder (Wiyani, 2013). ${ }^{8}$

As a detrimental action to humans, terrorism etymologically has four meanings. First, the attitude of intimidation; second, use of violence and intimidation especially for political purposes; third, terrorism is the use of violence in an effort to achieve goals; and fourth, terrorism is any action that creates an atmosphere of fear and despair.

The phenomenon vis-a-vis radicalism movement activities taking place within the scope of higher education must receive serious attention. Nevertheless, as the preceding step, we have to understand some characteristics of radical groups.

a. Often claiming a single truth.

b. Putting aside primary issues and prioritizing secondary issues in religious behavior. (Masduqi, 2013). ${ }^{9}$

c. Excessive behavior in religiosity that is not appropriate.

d. Having an emotional attitude as an effort to convince others in their preaching, speaking loudly, and being rude when interacting with other people

e. Tending to have prejudice against other parties.

f. If there are people who have different opinions from them, those people are considered kafir (infidels).

The methodology adopted in this study was a descriptive analysis, using a phenomenological approach that sought to reveal conceptual meanings or experiences-based phenomena pursuant to the occurring awareness. The data were collected using some techniques comprised of observations, interviews, and documentation. The sampling technique deployed snowball sampling. Research subjects in this study were the students of IAIN Curup who became the members of various student activity units and organizations of special activity units both inside and outside campus.

\footnotetext{
${ }^{8}$ Wiyani, N. A. (2013). Pendidikan Agama Islam Berbasis Anti Terorisme di SMA. Jurnal Pendidikan Islam . Vol. 2 No. 1. P. 72

${ }_{9}$ Masduqi, I. (2013). Deradikalisme Pendidikan Islam berbasis khazanah Pesantren. Jurnal Pendidikan Islam FTIK UIN Sunan Kalijaga . Vol. 2 No. 1. P. 3
} 


\section{Findings And Discussion}

\section{Understanding of radicalism among IAIN Curup students}

Radical understanding among the students of IAIN Curup is generally affiliated with religious radical understanding.

With Radicalism of religious understanding, people will act radically for various reasons. The foregoing could be because they are treated unfairly; then they no longer believe in the existing system; and they put up a fight with extreme actions. Religious radicalism could also be affected by political and economic reasons or other kinds of reasons.

In connection with religious radicalism, many people perceive it as someone's religious appearance is different from others in general, such as women wearing complete veils that cover their faces, men with beards wearing short pants. Many consider them the adherents of religious radicalism. In fact, this is a sort of depiction of the attitudinal firmness adopted by people who really want to apply Islamic law in their daily lives, in terms of appearance, deeds, and behavior according to the Qur'anic teachings and the Prophet's Sunnah, without having to force what they believe on others.

One of the IAIN Curup's students, FM, during a focus group discussion on November 16, 2018, told that the reasons for using the veil covering the face is as a form of concern with promiscuity that exists today. In such a way, the veil with face covering can better protect oneself from negative environmental influences, and can carry out Islamic law in accordance with the Qur'anic teachings and the Prophet's Sunnah.

The same thing was also conveyed by VR during a focus group discussion on November 16, 2018. She claimed to have worn the veil with face covering since the eleventh grade of senior high school. It was even long before she began attending Islamic sermons. She grounded her way according to a strong urge from her heart to practice the true Islamic law. Wearing the veil with face covering was also to protect her from negative influences of the surrounding environment. Wearing veil with face covering makes oneself protected from bad actions. 
It can be seen that the students' decision to wear veils with face covering is more grounded in the phenomenon of promiscuity among teenagers today. This drives their efforts to protect themselves and carry out the Islamic law in accordance with the Qur'an and the Prophet's Sunnah.

\section{Symptoms of radicalism among IAIN Curup students}

Symptoms of radicalism among students generally emerge from the entrance of sermons from outside the campus, with intensive discussion and sermon methods. Students are considered the most vulnerable to be influenced by new understandings because they are still in a period of searching for identity, so they feel safe and comfortable when they are engaged into a group with the same views and thoughts.

Generally, students who have participated in those sermons experience several changes in terms of appearance, attitude, behavior, and interactions with other students on campus. However, not a few stated that the changes made them more comfortable and convinced to change their appearance because they received supports from the sermon groups they participated in.

They are aware of various consequences that have to take along with the changes in appearance they made. It is natural that every choice made has consequences. One of which is the view of others who think that they have embraced radicalism. Such assumption comes not only from the people around, but also from the campus environment as well. To respond to this, not a few of them remain active in the various activities that exist on campus. They do not restrict their social interactions. They follow the campus organizations that they want by accepting every difference that exists in those organizations.

Therefore, it can be said that the students of IAIN Curup in general still have the spirit of Pancasila, Bhineka Tungga Ika, NKRI and the 45 Constitution.

\section{IAIN Curup's policies in an effort to ward off radicalism}


Basically, the efforts to counteract radicalism at IAIN Curup have been made through various policies in both preventive and curative ways. Accordingly, some policies are made as follows:

a. Providing materials about radicalism in the agenda of introduction to campus academic culture (in the Indonesian abbreviation, it is called PBAK) to new students.

b. Inviting the experts of radicalism understanding in some agendas such as coffee mornings, dialogues, and seminars with related parties at the campus.

c. Participating in anti-radicalism declarations held both regionally and nationally.

d. Supporting students' activities that take part in anti-radicalism declaration.

Meanwhile, in terms of strengthening religious understanding, the mastery of scientific fields, and the mastery of entrepreneurship, the campus has taken several concrete steps as follows:

Pertinent to strengthening religious understanding, it can be explained that Islam has enormous capital to encourage a harmonious life because the Qur'an explicitly explains the importance of positioning taqwa as the energy of tolerance. Differences in gender, nationality, and ethnicity should not hinder the efforts to welcome more harmonious days in the future. Therefore, the teachings of tolerance in Islam actually have a very strong and firm theological foundation because such teachings are driven by a spirit from God. God is the only One, while His creatures are definitely various.

Through strengthening as such, it is hoped that the entire campus academic community will be able to start to build tolerance towards the diversity of existing religious understandings, without being fanatical about one understanding, so that a harmonious campus life can be created.

Strengthening the scientific fields can be said to be a preventive step for those who have not been involved in the radicalism movement. Through preventive actions, the campus can instill a spirit of nationalism in students; students are able to have an open mind and become tolerant; they can be aware of provocation and incitement; they can build network 
in positive and peaceful communities; and they can carry out religious activities tolerantly. Mastery in science and technology is an important key in facing future's challenges. Science and technology will continue to develop, and those who do not master science and technology will be left out by nature. Facing increasingly complex problems and challenges calls for generations that are able to think creatively and innovatively, have character, and love alongside being proud of being the nation of Indonesia.

With strengthening the field of entrepreneurship, students are expected to have a creative and innovative spirit, be able to create new jobs so that they are not only anchored in merely one field of work. By so doing, students do not easily give up, that will lead them to negative thoughts contributing to radical actions.

\section{Conclusion}

Radical understanding amid the students of IAIN Curup is associated with radical religious understanding, but there is not found any symptom of radicalism. This can be generalized that the students of IAIN Curup still and consistently have the spirits of Bhineka Tungga Ika, NKRI, and the 1945 Constitution. The policies made by the campus in counteracting radicalism are by means of strengthening religious understanding, the mastery of the scientific fields, and entrepreneurship. Students have an understanding of religious tolerance and accept the presences of others. Being active in students' activities makes students stay focused on lecturing and learning objectives. Also, through entrepreneurship activities, students have a creative and innovative spirit so that they are not easily drawn into radical actions.

\section{References}

Ahnaf, M. I. (2013). Struktur Politik dan Deradikalisasi Pendidikan Agama Bagi Anak Muda Indonesia. Jurnal Pendidikan Islam FTIK UIN Sunan Kalijaga Yogyakarta. Vol. 2 No. 1

Hasan, K. (2000). Konsep Pendidikan Jawa. Jurnal Dinamika Islam dan Budaya Jawa, IAIN Walisongo Semarang . Vol. 3 No. 1

Masduqi, I. (2013). Deradikalisme Pendidikan Islam berbasis khazanah 
Pesantren. Jurnal Pendidikan Islam FTIK UIN Sunan Kalijaga . Vol. 2 No. 1

Qodir, Z. (2013). Deradikalisasi Islam Dalam Prespektif Pendidikan Agama. Jurnal Pendidikan Islam . Vol. 2 No. 1

Sedjana, E. (2008). Islam Fungsional. Jakarta: Rajawali.

Wiyani, N. A. (2013). Pendidikan Agama Islam Berbasis Anti Terorisme di SMA. Jurnal Pendidikan Islam . Vol. 2 No. 1

Yunus, A. F. (2017). Radikalisme, Liberalisme, dan Terorisme : Pengaruhnya Terhadap Agama Islam. Jurnal Studi Al-Qur'an .Vol. 13 No. 1 